\title{
IMAGENS E ANALOGIAS DO CORPO E DA MENTE NA POLÍTICA DE SPINOZA
}

Alexandre Arbex Valadares*

Resumo: O presente artigo propõe estudar algumas possibilidades interpretativas suscitadas pela analogia com que Spinoza busca ilustrar, a partir da imagem do corpo humano, a estrutura de composição do corpo político. Começando por discutir a dinâmica de produção de corpos na Natureza, o texto desenvolve uma análise da contradição entre duas teses, presentes na obra de Spinoza - uma, na sua ontologia, e outra, na política -, que se formulam nos termos da analogia do corpo humano com o corpo político; em seguida, essa analogia desdobra-se em uma comparação entre a mente humana e o que se poderia denominar uma "mente" do corpo político, a partir da distinção entre os dois níveis de constituição do político - a cidade (civitas) e o Estado (imperio); por fim, propõe-se uma interpretação do processo de produção de ideias e representações na vida política à luz da teoria althusseriana da ideologia.

Palavras-chave: Spinoza, política, corpo, imaginação, ideologia.

1.

A analogia entre corpo humano e corpo político é um lugar-comum da teoria política moderna, e denota influência, nestaúltima, das concepções organicistas ou atomistas de mundo. Mais que mero recurso retórico, que, aludindo a uma imagem-síntese, permite atalhar as dificuldades inerentes a uma explicação rigorosa do processo de constituição e funcionamento da vida social, a comparação confere evidência a dois princípios importantes do pensamento político pós-Maquiavel. O primeiro diz respeito à unidade do Estado, à sua integralidade ou ao seu caráter absoluto; o segundo concerne a algo que se poderia chamar identidade entre o todo e suas

*Doutorando em Filosofia pela Universidade Federal do Rio de Janeiro 
partes. Tal princípio permeia a tese contratualista do Estado fundado por homens, do Estado-instituição, que, reproduzindo em maior escala a concepção ideal do homem livre e racional, vincula o poder do soberano à sua vontade. A mesma ideia de identidade subjaz às interpretações relativas às condições de legitimidade do poder político, tanto nas teorias do pacto social, que consideram legítimo o poder absoluto emanado da vontade das partes, quanto nas teorias em que a legitimidade assume sentido realista, como em Maquiavel e Spinoza, e não se distingue do conjunto de relações de poder, ou de potência, que sustentam, no presente, certa autoridade ou instituição. Nesse caso, é dito legítimo o poder cuja constituição está de acordo com a natureza humana, não tal como a representam os moralistas, mas tal como ela se dá a conhecer na história e na experiência, isto é, marcada pelas paixões, pela imaginação e pelo conflito. Desse ponto de vista, a legitimidade não decorre propriamente do grau de adequação do poder político ao modo de ser dos homens, mas é, antes, por conformar-se à natureza destes que esse poder tem condições de se conservar; um poder político é legítimo na medida em que existe.

Que Spinoza se inspire em Maquiavel ao lançar mão da analogia entre corpo humano e Estado, o texto mesmo do seu Tratado político (TP, $\mathrm{X}, 1)$ nos autoriza a afirmar. Ele se refere, nessa passagem, ao trecho dos Discursos sobre a década de Tito Lívio em que Maquiavel compara um Estado sob risco de dissolução a um corpo doente, cuja situação tende a agravar-se caso não lhe seja aplicado o remédio ou tratamento clínico necessário. A imagem chama a atenção para um fato político essencial: nada ameaça mais a estabilidade de um Estado que seus inimigos internos. O Tratado teológico-político (TTP) faz advertência semelhante ao assinalar os riscos que uma guerra de religião pode acarretar ao Estado, mas esse perigo endógeno não é representado apenas pelos conflitos civis ou pelas conspirações nascidas no seio da aristocracia; a atuação de um legislador inepto e mesmo a opressão empreendida por um tirano contra os cidadãos são males igualmente nocivos à saúde do organismo político. No TP, Spinoza evoca a ideia de unidade ou integridade desse organismo, tanto para designar, como união de corpos, o processo de composição da potência coletiva que constitui a cidade (II, 15), quanto para descrever, como união de mentes, o direito da cidade fundado na razão (III, 7). Esse "corpo", a cuja imagem Spinoza assimila a política, é, pois, dotado de uma "mente", mas, em contradição com a concepção de natureza humana descrita na Ética (E), em especial com o princípio da independência dos atributos pensamento e extensão, essa mente parece exercer, pela vontade, algum poder sobre o corpo: o parágrafo 5 do capítulo III di-lo expressamente, e a definição, ainda que metafórica, do rei como "mente do Estado" no parágrafo 19 do capítulo VI reforça essa correspondência.

Essas passagens, claro está, têm sentido meramente ilustrativo: seus argumentos apelam à imaginação, e estão longe de sugerir um recuo de Spinoza em relação à sua crítica ao livre-arbítrio, abordada na Ética. Mas as aparentes incongruências entre sua política e sua ontologia não se restringem a esse tópico: o enunciado da proposição 4 da parte III da Ética, segundo o qual nenhuma coisa pode ser destruída senão por uma causa exterior, contradiz formalmente a tese, presente no TTP e no TP, que situa no interior do corpo político a principal fonte dos males que podem erodir a estabilidade do Estado. Tais contradições são irrespondíveis? Elas atestam, de fato, certo grau de autonomia da política de Spinoza em relação à sua ontologia, esta a desdobrar-se no conhecimento de segundo gênero, das noções comuns ou das ideias verdadeiras, enquanto aquela se vai instalar plenamente, ao lado da religião, no domínio das paixões e da imaginação, da experiência e da história? Seria desaconselhável, como tarefa filosófica, buscar a todo custo uma norma de conciliação que harmonizasse na coerência do sistema essas disparidades. Mas a correlação 
entre a imagem do corpo político como corpo humano, evocada nos dois Tratados, e a ideia de corpo, apresentada na Ética, permite propor uma interpretação da filosofia spinozista que, em consonância o parecer de Negri (4), identifica na ontologia de Spinoza a sua verdadeira política. É este o objetivo do presente estudo.

2.

A definição de "corpo humano", para Spinoza, não se distingue da definição de "corpo" em geral. Ela abrange dois aspectos principais: a individualidade complexa e a tendência à autoconservação. Um corpo é um indivíduo composto de outros corpos - ou de outros indivíduos - que se mantêm unidos entre si segundo uma relação determinada; essa relação, ou esse regime de composição, singulariza o corpo como um modo de existir, e ele existe na medida em que conserva ou reproduz essa relação. Noutros termos, essa relação é expressão da essência singular desse indivíduo, e singulariza-o, não como somatório de partes, mas como um regime ou uma lei determinada de composição que lhe é própria. A individualidade de um corpo não é definida pelas partes que o compõem: estas podem modificarse em cada atualidade em virtude da interação com outros corpos. O que distingue um corpo como indivíduo é o modo ou a relação segundo a qual as partes - ou outros corpos - entram na sua composição. A rigor, a tendência mesma de autoconservação do corpo envolve a regeneração de suas partes e o intercâmbio permanente com o exterior, isto é, com outros corpos que o afetam. Um alimento, por exemplo, agrega partes a um corpo, sem entretanto modificar sua relação essencial: essas partes compõemse com essa relação, ou, o que vem a ser o mesmo, conservam-na. Pode ocorrer, porém, que a afecção provocada por um corpo sobre outro não seja favorável à conservação deste; nesse caso, não há agregação de partes nem composição, mas, ao contrário, um processo de decomposição pelo qual as partes do corpo são determinadas, pela ação dos corpos exteriores, a entrar em outras relações diversas daquela que caracteriza o modo próprio de composição do corpo afetado e o distingue como um indivíduo singular.

Ora, se a essência de um indivíduo é a lei de composição ou a relação característica sob a qual outros corpos ou partes, mantendo-se unidos entre si, distinguem-no como corpo complexo existente, então nada que decorra dessa essência pode destruir o indivíduo. A essência de uma coisa existente não se diferencia da sua tendência de autoconservação. É este o sentido da afirmação de Spinoza segundo a qual nenhuma coisa pode ser destruída, senão em virtude de uma causa exterior (E, III, 4). A noção de "exterior", a que Spinoza alude nesse caso, não diz propriamente respeito ao que é externo ao corpo, ao que está "fora": os choques dos corpos exteriores, percebidos sob a forma de afecções ou modificações em nosso corpo, podem, de acordo com as condições em que se dão esses choques, decompor as nossas relações características, ou seja, as relações em que nossa essência se expressa como um modo de existir ou como um modo da extensão, mas, ao mesmo tempo, a conservação desse corpo depende da regeneração constante de suas partes constitutivas, de um intercâmbio ininterrupto com os outros corpos. Dizer que uma coisa favorece a conservação das relações de movimento de um corpo (E, IV, 39) é o mesmo que dizer que ela aumenta a capacidade desse corpo de ser afetado por outros corpos (E, IV, 38), isto é, de abranger um maior número de partes (ou de corpos menos complexos) sob sua relação característica, ou, dito de outra maneira, de estender a sua lei de composição própria sobre outros corpos. Por essa razão, um corpo é tanto mais apto a conservar-se quanto mais é capaz de ser afetado por outros corpos, e não na medida em que é capaz de se defender deles ou evitá-los. Do exterior, do mundo da extensão, vem todo bem e todo mal: a conservação e a destruição de um corpo explicam-se pelas condições em que ele se encontra ou se choca com outros corpos. 
Um corpo está em comunicação permanente com os corpos exteriores, ou, mais exatamente, as partes ditas internas de um corpo estão em contato contínuo com partes externas a esse corpo, integradas às relações características de outros corpos. A rigor, como observa Deleuze (2002), a distinção entre "exterior" e "interior” não é real: o exterior é um interior projetado, e o interior é um exterior introjetado. Supor semelhante separação significaria considerar a extensão um continente de corpos, isolados uns dos outros por espaços vazios. Mas a extensão, para Spinoza, é um atributo infinito de Deus, ou da Natureza, que se apresenta sempre e já na forma de uma modificação infinita e imediata - o movimento, ou as relações de movimento e repouso -, e, a partir desta, na forma de uma modificação infinita e mediata - a figura do universo em sua totalidade (facies totius universi) (Carta 64 a Schuller). Essa figura total do universo é, por assim dizer, a imagem da permanência, da eternidade, do universo como totalidade material; ela se refere ao que, a despeito das ilimitadas variações que os corpos sofrem, dos desdobramentos sucessivos das relações de movimento e repouso, segue sendo constante no universo: o fato de ele se apresentar como existência material infinita. Os corpos são modos finitos da extensão, efeitos materiais das relações de movimento e repouso, que exprimem as infinitas variações singulares, e de duração limitada, da facies totius universi. É o jogo das relações de movimento e repouso que determina a duração do corpo: sua conservação ou seu aniquilamento advém das relações com os outros copos, das relações através das quais suas partes entram em contato com as partes de outros corpos, ora compondo-se com elas segundo a sua relação característica - que define o modo como sua essência se exprime na extensão -, ora compondo-se com elas segundo outras relações que não a que o caracteriza, de sorte que sua essência deixa de ter expressão na extensão, ou seja, de sorte que tal corpo decompõe-se, deixa de existir.
A extensão, como o pensamento, é um dos infinitos atributos de Deus, isto é, Deus pode ser concebido como coisa pensante e como coisa extensa. $\mathrm{O}$ atributo tem um sentido adjetivo em relação à Substância, que é Deus ou a Natureza. O modo infinito mediato da extensão - a facies totius universi - concerne ao mundo material infinito, designa o que se poderia chamar o "corpo" de Deus. Quanto ao atributo pensamento, também constitutivo da natureza divina infinita, pode-se supor, além de um modo infinito imediato - o intelecto infinito de Deus -, um modo infinito mediato - a ideia infinita de Deus, que, por analogia, se assimilaria à "mente" de Deus. A mente divina seria, portanto, a ideia infinita que abrange todas as ideias das modificações da natureza de Deus. Contudo, se as relações de movimento e repouso no atributo extensão dão existência aos corpos singulares ou a suprimem, mas segundo a dinâmica de produção da existência eterna e infinita de Deus como coisa material, as ideias se afirmam todas simultaneamente na ideia infinita de Deus; a rigor, quer um modo singular exista ou não exista, é possível formar uma ideia a seu respeito: ele é pensável, sua ideia compõe-se com as outras ideias no atributo pensamento, assim como as essências de todas as coisas se compõem na essência eterna e infinita de Deus. Se, na extensão, a dinâmica de produção e destruição dos corpos singulares inspira a imagem da finitude, isto se deve a que os homens são determinados a perceber seus próprios corpos como entes materiais distintos, separados dos outros corpos, ante os quais exerce sua potência de existir e de agir, cujos limites são assinalados pela potência de existir e de agir de todos esses outros corpos.

Essa dinâmica concorrencial que, do ponto de vista dos modos singulares da extensão - dos homens -, parece presidir aos choques e encontros dos corpos, não explica o processo de produção da existência eterna e infinita de Deus. Do ponto de vista da totalidade - de Deus ou da Natureza -, não há decomposição: dos choques e encontros dos corpos 
resulta sempre a afirmação de uma coisa como existente, isto é, um modo de ser que exprime, em grau limitado, finito, o ser ou essência eterna e infinita de Deus, concebido pelo atributo extensão. Os choques ou encontros entre os corpos, decorrentes das relações de movimento e repouso, constituem o modo infinito imediato pelo qual a existência de Deus ou da Natureza é produzida eterna e infinitamente. O processo de constituição da realidade é um processo de produção de existências singulares por composição de corpos, determinado pela ordem das relações de movimento e repouso. A infinita variedade dos modos de ser ou essências singulares que ganham atualidade ou passam à existência a partir dessas relações explica a heterogeneidade do real; por outro lado, uma vez que cada corpo exprime, em certo grau, a essência ou o ser de Deus concebido pelo atributo extensão, isto é, uma vez que cada corpo, ao mesmo tempo que afirma sua essência como existente, afirma a materialidade do real, este se apresenta sempre sob a unidade homogênea e permanente da facies totius universi.

No entanto, as leis de produção dos modos no atributo extensão, ou, para dizer o mesmo, as leis de movimento que determinam que as partes extensas se agreguem ou se desagreguem sob a forma deste ou daquele conjunto corporal, podem, em seus efeitos, ser destrutivas para um corpo em particular. Da perspectiva da totalidade, de Deus, não há decomposição: todos os efeitos que se desdobram na extensão afirmam a essência de Deus sob este atributo, exprimem-na em grau determinado, e integram a facies totius universi; quando um corpo em particular é destruído, isto significa que, na ordem de produção da existência de Deus ou da Natureza, se deram causas que excluem a existência singular desse corpo, ou que os demais corpos que, nesse processo causal, entraram em contato com ele infligiramlhe modificações que alteraram o regime de composição de suas partes, e estas passaram a agregar-se sob outras relações estranhas à essência desse corpo; noutros termos, embora a essência desse corpo não se perca com a sua aniquilação, isto é, embora a essência siga sendo concebível sob outros atributos, ela não se concebe mais sob o atributo extensão, não se exprime mais sob a forma de um modo desse atributo. A identidade entre a ordem de produção das ideias e a ordem de produção das coisas, tal como enunciada na proposição 7 da parte II da Ética, não justifica a suposição, demasiado citada entre comentadores, de um paralelismo entre o atributo pensamento e o atributo extensão: por "coisas", deve-se entender "essências", e não "corpos". A ordem de produção destes, conquanto não possa ser distinta da ordem de produção das ideias - uma vez que exprime sempre a mesma essência de Deus -, não a espelha nem a reproduz em ato: a duração indefinida da existência dos corpos não se confunde com a eternidade das ideias adequadas ou das ideias das essências, que podem referir-se a coisas existentes ou não existentes na extensão.

Como é preciso compreender, à luz das considerações precedentes, a proposição segundo a qual uma coisa não pode ser destruída senão por uma causa exterior? Que um corpo seja destruído, que as suas partes sejam determinadas a entrar em outras relações em virtude da ação de outros corpos, é algo que a simples experiência permite perceber: um corpo dotado de uma propriedade corrosiva, por exemplo, pode extinguir outro cuja natureza não seja capaz de assimilar seus efeitos; um corpo, que nos convém sob uma dada relação (combinado a outros corpos ou em certas quantidades, como o remédio), pode tornar-se-nos letal sob uma relação diferente (o veneno). Mas não é disso que trata a proposição. As coisas são destruídas pelo que é exterior, não propriamente ao seu corpo - porque sua conservação depende do intercâmbio com corpos externos -, mas à essência delas. A afirmação da essência de uma coisa entra em contradição com a afirmação da essência de outra coisa: suas definições se limitam ou se excluem na mente. Mas, se uma ideia limita outra ideia, e um corpo limita outro corpo (E, I, def.2), a contradição lógica no pensamento se exprime 
como conflito físico na extensão (MATHERON, 3); e, da mesma maneira que, por um lado, a afirmação de uma essência, no pensamento, dá-se como ideia verdadeira ou adequada, como modo de pensar que persevera no seu ser, na sua verdade intrínseca, a afirmação dessa essência como coisa existente na extensão, como corpo, toma a forma de uma tendência de autoconservação.

Um corpo individual é sempre complexo: ele é um composto de corpos, unidos, como suas partes constitutivas, por uma relação característica segundo a qual elas comunicam entre si certa quantidade de movimento, ou seja, certa potência; o que torna singular um indivíduo corporal é, não o número de suas partes - que é sempre infinito-, mas a relação específica que as agrupa e que, exprimindo a essência desse corpo, exprime a potência que afirma essa essência como coisa existente na extensão, na materialidade. A potência do corpo é uma potência causal, cujos efeitos concordam com sua essência, e, nessa medida, favorecem a tendência de autoconservação do corpo; noutras palavras, os efeitos que se seguem da potência de um corpo, de sua ação, ainda que possam diferenciar-se quanto aos objetos sobre os quais se aplicam, têm em comum o fato de concorrerem para a conservação desse corpo, não porque a dinâmica interna deste seja animada por uma teleologia, por um finalismo, mas porque esses efeitos se explicam sempre pela essência singular desse corpo e afirmam, na extensão, a relação característica ou a identidade dominante que exprime essa essência. Quer isto dizer que o corpo reproduz indefinidamente as condições de sua própria atividade, isto é, a relação característica, estrutural, que o singulariza como um composto de corpos, investido, por assim dizer, de certo quantum de movimento, de uma potência que afirma, em face de outros corpos, a tendência de autoconservação desse corpo singular. Bove (2) encontrará aí o fundamento da ideia segundo a qual os homens, na condição de modos finitos de ser cuja essência se exprime simultaneamente como modo de existir - corpo - e como modo de pensar - mente -, são definidos por uma dinâmica interna de resistência.

A mente é uma ideia do corpo, um modo de perceber o corpo. Mas mente e corpo não produzem efeitos um sobre o outro; os efeitos que limitam a maneira pela qual uma essência singular se afirma, ou seja, que definem a potência com que tal essência se expressa como realidade, se encadeiam de maneira independente e distinta em cada atributo. Cumpre assinalar que essa correlação não presume uma duplicidade de efeitos; pensamento e extensão são atributos de uma substância única, assim como a mente e o corpo são apenas modos através dos quais se exprime uma mesma essência singular, modos de a conceber em relação a outras realidades, outras essências singulares. Quanto ao atributo pensamento, o efeito de uma ideia dada sobre nossa mente (ela própria uma ideia) pode ou determiná-la a produzir uma ideia adequada ou verdadeira, caso em que a ideia dada favorece a potência de pensar da mente e lhe permite afirmar a existência do nosso corpo como expressão de nossa essência adequadamente concebida; ou pode, por outro lado, determiná-la a gerar uma ideia inadequada ou falsa, caso em que a ideia dada limita a potência de pensar da mente e a coage a afirmar, não a existência de nosso corpo, mas a de um corpo externo, cuja imagem é ligada à ideia dada. Quanto à extensão, o efeito de outro corpo sobre nosso corpo pode ou favorecer nossa tendência de autoconservação e a potência que a realiza, caso em que suas partes compõem-se com as partes que nos constituem, sob a relação característica que as mantêm unidas e na qual se exprime nossa essência singular; ou pode limitar essa tendência de autoconservação, caso em que suas partes não se compõem com as nossas e, assim, tornam instável a relação característica sob a qual elas se mantêm unidas, a ponto de desfigurá-la de forma que tal relação perde em alguma medida sua identidade com nossa essência, e esta já não pode afirmar-se, com a mesma 
potência, como coisa existente na extensão.

Mas, se está claro que, na extensão, a contradição ou o efeito de afecções contrárias à nossa essência (que se exprime na extensão, vale repetir, como tendência de autoconservação) se apresenta como ameaça à integridade do corpo, é possível todavia afirmar que o corpo é sujeito de contrários, um "lugar de guerra", de conflito? Como observa Bove (2, p.13), os corpos podem ser sujeitos de contrários, ou seja, podem sofrer afecções ou modificações que se opõem à sua tendência de autoconservação, desde que essa contradição não atinja a "a identidade dominante do corpo na relação de suas partes". A dinâmica interna do corpo caracterizar-seia, então, como um esforço de resistência, que buscaria expulsar de si a contradição, deslocando-a indefinidamente, e empregando, nesse esforço, sua potência, determinada pelas condições atuais em que o problema da autoconservação se lhe apresenta. O corpo não é, entretanto, um substrato onde se desenrola o conflito; tal conflito constitui a determinação atual desse corpo, e prescreve, na extensão, o espaço e a duração da expressão de sua potência. Um corpo é um complexo de relações de força, de potências que se afirmam umas sobre as outras, ao mesmo tempo que se conjugam em uma potência mais complexa, que afirma a existência desse corpo como uma indivíduo singular (composto).

O princípio de resistência identificado por Bove na tendência de autoconservação do corpo faz supor, entretanto, que a perseverança indefinida do indivíduo na existência tem, no conflito, a sua dinâmica fundamental. Pode-se, decerto, afirmar que o corpo é sujeito de contrários, na medida em que é sujeito a afecções que limitam sua tendência de autoconservação, isto é, na medida em que sofre modificações cujas causas não se explicam pela sua essência e cujos efeitos, por essa razão, não favorecem a potência que afirma essa essência como existente. Contudo, o indivíduo corporal não persevera na existência em reação a outros corpos que se lhe opõem, isto é, não realiza a sua autoconservação pela destruição de tudo quanto não se submeta à lei de sua essência singular. A exposição constante do indivíduo a afecções contrárias traduz uma condição própria dos modos finitos: sua passividade. E tal condição não engendra um poder de resistência. Os indivíduos, de fato, afirmam sua potência sempre no âmbito das relações sob as quais entram em contato uns com os outros, e sua potência é limitada pela estrutura mesma dessas relações, mas a expressão dela não é uma forma de reação pela qual ela responderia a uma causa externa: ela é sempre expressão da essência singular do indivíduo, e se explica, não pela sua "pessoalidade", pela sua existência, mas, antes, pela participação do indivíduo no processo de produção da Natureza, pelo grau determinado com que a potência de Deus ou da Natureza produz, a partir dessa essência singular, os efeitos que dela se seguem necessariamente. Isto significa que a potência de agir dos indivíduos não atende ao objetivo de conservar seu corpo, como se ele pudesse captar a potência de Deus ou da Natureza para fazê-la servir a essa finalidade; a conservação do corpo é um efeito da afirmação de uma essência singular, que se exprime como modo da extensão, mas essa essência não envolve a existência do corpo. Se, por certo, não há distinção real entre uma coisa e sua tendência a perseverar no ser, é porque sua essência concorda com sua potência, e ambas são apenas expressões ou modos de ser da essência de Deus e da potência de Deus. A potência singular individual é antes uma potência causal que uma potência de autoconservação: a conservação de um indivíduo explica-se, pois, menos por sua capacidade de resistência que pela sua capacidade de produção de efeitos necessários do ponto de vista da essência de Deus, não em termos absolutos, mas na medida em que ela se exprime na forma de sua essência singular.

Ora, dizer que o indivíduo é uma potência causal não é senão afirmar que sua potência se integra à ordem de produção do ser, à ordem 
de produção das coisas, como consta na proposição 7 da parte II da Ética. Essa produção, no atributo extensão, se realiza por composição de corpos, segundo relações de movimento e repouso. Por isso, a tendência de autoconservação dos corpos ou a dinâmica interna dos indivíduos corporais encontra sua razão fundamental, não em um princípio de resistência, mas em um princípio de composição, de união; essa diferença pode ser entendida, do ponto de vista dos homens, como uma regra de prevalência do indivíduo, complexo de corpos em constante modificação e definido por uma relação característica, sobre o sujeito, "lugar" de contrários, em cujo interior uma potência de permanência, de afirmação do "mesmo", reage em face do "outro", das afecções ou modificações que a limitam.

3.

A concepção spinozista de indivíduo envolve três elementos essenciais: a) a complexidade, isto é, sua natureza composta; b) a relação característica que conserva essa composição, ainda que suas partes constitutivas se modifiquem de momento a momento; e c) a tendência à autoconservação, que não se distingue do grau de potência que a realiza, ou seja, da força pela qual o indivíduo persevera no seu ser. Nos indivíduos humanos, na medida em que são constituídos de um corpo e uma mente, essa tendência à autoconservação exprime-se, por um lado, por meio de uma prática material, da busca pelas coisas úteis e necessárias à existência, ou das coisas que se compõem com a natureza do indivíduo e cujas partes se integram, preservando-a, à sua relação característica, e, por outro lado, por uma reflexão ou imagem consciente através da qual o indivíduo percebe essa prática e afirma, à luz dela, a continuação de sua existência. Esse conceito de indivíduo, abrangendo corpo e mente, deve repercutir sobre a analogia traçada por Spinoza entre o ser do homem e o ser da política. Noutros termos, a sociedade pode ser compreendida como um indivíduo extraordinariamente complexo, definido por uma tendência de conservação, de reprodução do modo de ser desse indivíduo, ou de reprodução das relações constitutivas que o caracterizam, e por uma imagem ou representação mental, igualmente complexa, dessas relações e das práticas que delas decorrem.

As relações constitutivas de um corpo político, como as relações dos corpos em geral, são relações de potências ou de forças que se afirmam umas em face das outras, mas das quais resulta, ao mesmo tempo, certo regime de composição, que as agrega em uma potência tão complexa quanto a união das partes que se conjugam na sua constituição e que responde pela conservação do corpo político em sua totalidade. Está visto que uma coisa só pode ser destruída por uma causa exterior, e que, se é possível afirmar que o corpo é sujeito de contrários ou lugar de modificações que se opõem à conservação de sua existência, é apenas na medida em que elas não pertencem à sua essência ou não se encadeiam, nele, segundo a relação característica em que a essência desse corpo se exprime. Esta dicotomia entre o conflito de potências das partes constitutivas de um corpo e a unidade de afirmação da potência através da qual esse corpo, como indivíduo complexo, se conserva é, do ponto de vista da política, o fundamento da ideia segundo a qual o maior perigo à estabilidade de um Estado reside em seu interior: é a guerra civil. Hobbes, a propósito, sustenta que o medo à guerra generalizada é o que compele os homens a aderir ao pacto e a obedecer à vontade do soberano, renunciando ao direito natural de se conduzir segundo a sua própria vontade. Isto significa, em primeiro lugar, que o estado civil seria um estado de trégua, não propriamente de suspensão do conflito que está na sua gênese, mas, ao contrário, de reprodução das condições de determinação desse mesmo conflito e, com elas, da necessidade de reiterar, eventualmente com mais rigor, a adesão dos cidadãos ao pacto. A guerra civil, assimilada ao estado de natureza, 
corresponderia, por assim dizer, à ideia latente da qual o estado civil seria o conteúdo manifesto. Além disso, o pacto hobbesiano supõe que esse conflito fundamental só pode reduzir-se a uma unidade a partir de uma extrema polarização: a transferência de todos os direitos naturais a uma autoridade cujo mandato é fazer cumprir o pacto social, isto é, a trégua, e que, para tanto, é investida de um poder absoluto.

Para Spinoza, o poder constituinte da vida civil não se dissocia da própria potência coletiva resultante da composição das potências singulares de seus cidadãos. A multidão, nome que Spinoza dá a essa composição, não subentende, está claro, uma conciliação perfeita em uma unidade formada por simples agregação de partes: ela engloba, na sua individualidade complexa, os conflitos existentes nas relações entre suas partes, isto é, nas relações entre os cidadãos. Mas, se a constituição da vida civil envolve algum grau de contradição, ou, noutros termos, se também a multidão pode ser "sujeito de contrários", por outro lado somente ela atua como poder constituinte precisamente porque tal contradição não pertence à sua essência nem se exprime nas relações que a caracterizam - a multidão é, com efeito, segundo observa Bove (2, p.12), atravessada de conflitos e contradições, e, contudo, ela afirma, com a potência coletiva que a define, uma unidade política. A questão está, pois, em explicar o processo de constituição dessa potência ou, mais pontualmente, em compreender por que os homens se tornam cidadãos, por que eles constituem uma cidade.

A teoria spinozista do direito natural permite-nos lançar uma primeira luz sobre essa indagação. Spinoza não faz distinção entre o direito natural e a potência singular de um indivíduo: o direito deste sobre a natureza vai até onde vai sua potência de agir, e tudo quanto um indivíduo faz em virtude de sua potência singular pertence ao seu direito natural. Isto significa que o direito natural de um indivíduo não atende a nenhum outro critério de legitimidade senão à sua própria potência, e esta coincide perfeitamente com a existência atual desse indivíduo. Cada indivíduo existe tanto quanto está em sua potência afirmar-se como existente. A potência singular é sempre em ato; o direito natural não é uma faculdade de agir, mas uma ação necessariamente determinada, uma necessidade em ação. Potência singular e direito natural são apenas a expressão de uma essência singular que persevera no seu ser, ou, do ponto de vista do corpo, a expressão da tendência de autoconservação da existência. Todos os homens buscam conservar-se, e recorrem a todos os meios que estão em sua potência para tanto. Spinoza (E, III, 9) afirma que todos os homens são conscientes disso, o que não quer dizer senão que eles percebem uma conexão imaginária ou real entre, de um lado, seu modo de agir ou operar no mundo, e, de outro, o desejo de permanecer em vida.

Essa tendência pela qual os homens são determinados a perseverar no ser opera neles em dois níveis diferentes.

Em um primeiro nível, o da imaginação, essa tendência toma a forma específica de um desejo, que se dirige a um objeto específico, representado por este mesmo desejo como algo bom ou útil porque causa um acréscimo de potência, sentido sob a forma de uma paixão, um afeto passivo porque se prende à imagem do objeto externo, representado como sua causa. Assim, um homem imagina que deseja uma coisa não porque ela lhe é boa ou útil sob dada relação, mas porque ela é boa ou útil em si mesma, ou melhor, porque ela é um Bem, uma vez que a alegria passiva que ele sente ao imaginá-la sob sua posse parece depender da natureza própria dessa coisa. Essa percepção invertida constitui, com um só movimento, a forma da consciência, ou seja, a demarcação entre um sujeito e um objeto, e o conteúdo moral desta consciência, que representa as imagens das coisas como valores. Mas essa percepção imaginária ou inadequada não é rigorosamente falsa: embora os homens ignorem as causas verdadeiras em virtude das quais tendem a buscar tais coisas, eles percebem, simplesmente 
porque são determinados a desejá-las e se alegram com sua posse, que elas favorecem a sua potência de perseverar no ser. $\mathrm{Na}$ ignorância das causas, o desejo e os afetos alegres são guias seguros na busca das coisas que lhes são úteis, e a imaginação que os induz a considerar tais coisas como causas do desejo ou da alegria representa essa busca como uma teleologia ou como um finalismo da ação, orientado por ideias valorativas ou juízos morais.

Mas, em um segundo nível, o da razão, essa tendência de perseverar no ser envolve uma ideia verdadeira da utilidade recíproca dos homens, ou, o que vem a ser o mesmo, uma noção comum da utilidade. Essa noção comum não tem outro ponto de partida que os afetos passivos e as ideias inadequadas da imaginação; contudo, nesse segundo nível, já não se trata de ideias de objetos externos, de ideias de imagens, e sim de ideias de relações. Um homem não considera como intrinsecamente boas ou úteis as coisas para as quais tende; elas lhe parecem boas ou úteis na medida em que ele entretêm com elas uma relação favorável à sua potência, isto é, na medida em que compreende essa relação como uma composição entre a sua natureza singular e a natureza das coisas. Ora, essa composição favorável só pode ocorrer se as relações que um homem estabelece com as coisas que o afetam se realizam por meio das propriedades comuns de seus corpos. É certo que, no nível da imaginação, ainda que um homem suponha que sua alegria derive do fato de ele - sujeito - ter entrado na posse do objeto desejado, o que ocorre não é senão uma relação de composição entre a sua e a natureza desse objeto, a partir de suas respectivas propriedades comuns. Mesmo que, na imaginação, a causa dessa alegria seja percebida por uma ideia inadequada, no plano das essências, do real, o que a explica é uma composição de naturezas; noutros termos, os homens podem estabelecer composições favoráveis à sua potência - e são determinados a isso pelo desejo -, pondo-se em relação com outros corpos a partir de suas propriedades comuns, sem necessariamente terem uma ideia dessa relação, isto é, uma noção comum.
Uma noção comum se produz quando é dado ao homem apreender as causas verdadeiras de uma afecção ou de uma modificação percebida no seu corpo. Spinoza $(E, I, 3)$ afirma que apenas as coisas que têm propriedades em comum com nossa natureza podem causar modificações em nós. Isto significa que os efeitos produzidos em nós pela ação de outros corpos envolvem sempre as propriedades comuns existentes entre nossa natureza e a desses corpos, e, por conseguinte, as ideias dessas modificações ou afecções, pelas quais elas são percebidas, envolvem essa relação. Esse conteúdo verdadeiro, porém, não se nos apresenta, por assim dizer, em estado puro, como uma ideia verdadeira dada. Ele reveste, quase sempre, uma forma falsa ou inadequada: ao percebermos uma afecção, somos determinados a considerar a imagem do corpo externo que nos afeta, uma imagem parcial, na medida em que é delimitada pela parte do nosso corpo que é afetada; e, assim, acabamos por confundir essa imagem parcial com a natureza do corpo externo, julgando-a boa ou má segundo essa afecção nos cause alegria ou tristeza, favoreça ou diminua a nossa potência singular. Podemos formar noções comuns apenas quando nos é possível encadear essas ideias de imagens ou ideias de afecções, não na ordem acidental em que as percebemos na sucessão dos choques e encontros de corpos na natureza, mas na ordem necessária de sua produção, isto é, quando nos é possível relacionar uma ideia de afecção e outra ideia de afecção a partir das propriedades comuns que nelas se afirmam e por meio das quais o intelecto pode transigir de uma à outra. Uma vez que a noção comum é a ideia da relação entre as propriedades comuns de nosso corpo e do corpo que nos afeta, propriedades estas que explicam por que esse corpo pode ser causa de modificações em nós, é apenas em presença de uma afecção que favoreça nossa potência de agir, ou seja, de uma relação de composição, que temos condições - necessárias, mas não suficientes - de apreender a noção comum; do ponto de vista dos afetos, apenas em estado de alegria 
podemos efetuar essa passagem.

O processo de constituição da sociedade política - ou da cidade - sintetiza esses elementos conceituais, e permite reintroduzir a questão do direito natural. Spinoza, como foi visto, considera esse direito idêntico à potência singular dos indivíduos, a potência pela qual eles agem, com todos os meios de que dispõem, para conservar sua existência. No entanto, tomada em si mesma, e em oposição à potência de todas as coisas exteriores, essa potência singular em que consiste o direito natural individual tem uma existência puramente hipotética; Spinoza chamá-la-á no TP (II, 15) de simples abstração. A potência singular de um homem é infinitamente ultrapassada pela potência que sobre ele exercem os corpos externos.

Os homens são partes da Natureza ou modos de ser de Deus que não existem por si mesmos, isto é, modos de ser cuja essência não envolve a existência; em outros termos, nenhum homem é de constituição corporal ou mental tão complexa que possa, contando apenas com sua potência, produzir todas as coisas de que necessita para seguir vivendo. Por isso, a tendência mesma que determina os homens a buscar na Natureza as coisas que são boas ou úteis à conservação de sua existência determina-os a compor sua potência singular com outras potências singulares, a formar, pois, uma potência mais complexa, por meio da qual possam produzir coletivamente as coisas de que têm individualmente necessidade. Quanto mais propriedades comuns houver entre a natureza de um homem e a natureza de outros corpos, tanto mais lhe é possível estabelecer com eles relações de composição que favoreçam a sua potência singular; assim, uma coisa é tanto mais útil ou boa para um homem quanto mais propriedades comuns houver entre suas naturezas singulares, quanto mais essas forem semelhantes entre si. Ora, na Natureza, a coisa que mais tem propriedades comuns com a natureza singular de um homem é a natureza singular de outro homem; isto quer dizer que, quando um homem se empenha na produção de efeitos que favoreçam a afirmação de sua potência ou a conservação de seu ser, esses efeitos são igualmente úteis ou bons a todos os corpos de natureza semelhante à sua, ou seja, a todos os homens; por isso, na Natureza, nada é mais útil ao homem que outro homem (E, IV, 35).

Este enunciado traduz a ideia de utilidade recíproca dos homens, descrita no quinto capítulo do TTP como um processo de divisão social do trabalho, que se explica, por um lado, pela tendência em virtude da qual os homens são determinados a buscar as coisas necessárias à conservação de sua existência, e, por outro, pela impossibilidade de empreenderem essa busca contando somente com sua própria potência singular. Os homens, diz Spinoza, precisam alimentar-se, vestir-se, proteger-se contra as intempéries, alegrar o espírito e muitas outras coisas cujas exigências excedem os limites de sua potência. Eles não podem ser suficientemente hábeis em todas as tarefas, não dispõem de tempo para executá-las, e, ademais, em boa parte de suas vidas, na infância, na doença ou na velhice - que nada mais são que afecções ou modificações impostas ao seu corpo pela ação dos outros corpos existentes na Natureza -, têm reduzida a sua capacidade de agir, a ponto de dependerem, com frequência, da potência de outros homens para obter as coisas de que necessitam. Ao mesmo tempo, porém, como as naturezas singulares dos homens têm numerosas propriedades comuns entre si, o alimento que um homem cultiva e o nutre, o agasalho que fabrica e o protege, a casa que constrói e o abriga, ou a música que ele compõe e o enternece, são coisas úteis à conservação da existência de todos os indivíduos cujas naturezas são-lhe semelhantes. Essa utilidade recíproca explica por que o modo pelo qual os homens tendem a conservar sua existência determina-os a estabelecer relações uns com os outros, a compor entre si suas respectivas potências singulares, de maneira que, através da potência coletiva assim constituída, possam produzir as coisas necessárias às suas existências individuais. As relações 
de composição de potências singulares são, pois, relações de produção, e a potência coletiva que se forma a partir destas - a potência da multidão - é o próprio fundamento constituinte da vida política, da cidade. É apenas na vida política, na constituição de relações de composição de potências em um processo de produção comum das coisas necessárias à existência, que os homens podem realizar o seu direito natural de autoconservação; a natureza dos homens é, pois, política (TP, II, 15).

\section{4.}

Ao afirmar que nada é mais útil ao homem que outro homem, Spinoza promove a desalienação da idéia de Bem: ele a desloca de um objeto, representado pela imaginação como bom em si mesmo, como portador intrínseco de um valor, para situá-la em uma relação. Mas esta diferença indica também por que uma mesma coisa pode ser-nos útil ou nociva $(\mathrm{E}$, IV, 30): sua utilidade é acidental, ou seja, não decorre de uma propriedade inerente à natureza da coisa, mas se explica pela relação sob a qual ela nos afeta e pelo modo sob o qual essa relação é percebida por nós. Spinoza afirma que os homens, quando dominados pelas paixões, são inconstantes e variáveis, a ponto de não ser possível dizer que suas naturezas concordam entre si: eles podem, com efeito, opor-se uns aos outros (Et., IV, 32) e perceber suas relações mútuas, não sob a ideia verdadeira de sua utilidade recíproca, mas sob a imagem de um antagonismo que os representa uns para os outros como causas de afecções que limitam sua potência de agir e os afetam de tristeza. Se, por exemplo, os homens aspiram a um mesmo bem, representando-o como causa de alegria, é certo que suas naturezas estão de acordo, e o desejo que cada um sente de possuir esse bem é alimentado pelo desejo similar do outro. Eles passam a diferir em natureza, no entanto, se, imaginando que esse bem só pode ser apropriado por um deles em detrimento do outro, são afetados de paixões divergentes, na medida em que um o possui e o outro o perde. Então, imaginando cada qual que a alegria de um é causa da tristeza do outro, ou seja, que a apropriação por um deles desse bem desejável exclui o outro de sua posse, tais homens odiar-se-ão, e desejarão destruir-se (E, IV, 34 esc.).

Contudo, essa ideia de utilidade recíproca não é auto-evidente. Em suas relações, os homens não se governam orientados pela noção comum de que dependem uns dos outros, e não é raro, como a história e a experiência atestam, que grandes rivalidades, nascidas das paixões, se enraízem entre eles. O conflito marca a vida política precisamente porque a imaginação e as paixões constituem a forma imediata e universal pela qual os homens percebem o mundo em que vivem e se relacionam uns com os outros. Tal percepção não é unívoca nem invariável: ela é atualizada constantemente, em cada indivíduo, a partir das modificações ou afecções de seu corpo. As afecções do corpo são percebidas, na mente, sob a forma de ideias de afecções. As ideias de afecções são ideias das imagens das partes do corpo afetadas e, portanto, representam, na mente, o estado atual do corpo, sua existência em ato. Mas as ideias de afecções não são causadas pelas afecções: como a natureza de um homem, sua essência singular ou seu modo de ser, exprime-se, simultaneamente, como um modo de existir na extensão - o corpo - e um modo de pensar - a mente -, cada modificação ocorrida na natureza desse homem exprime-se como uma modificação do corpo e uma modificação correspondente da mente. Noutros termos, seguindo-se uma afeç̧ão no corpo, é impossível que não se siga uma ideia dessa afecção na mente, através das qual essa afecção é percebida ou representada. Essa afecção pode convir ou não à essência singular de um homem, compor-se ou não com ela, favorecer ou limitar a sua potência: em caso positivo, ele perceberá essa variação sob a forma de um afeto de alegria; em caso negativo, sob a forma de um afeto de tristeza.

Os afetos são sintomas da variação da potência singular, e esta 
aumenta ou diminui segundo as afecções sofridas pelo corpo concordem ou não com sua natureza, isto é, componham-se ou não com ela a partir de suas propriedades comuns. Um afeto, entretanto, é dirigido ao objeto externo que é causa da afecção e cuja imagem é representada na ideia dessa afecção. Nesse nível de percepção - o da imaginação e das paixões - duas ilusões se infiltram: em primeiro lugar, a afecção, que é sempre parcial, circunscrita à forma da relação sob a qual um corpo nos afeta, é inadequadamente apreendida como uma expressão da natureza ou essência desse corpo, e a ideia dessa afecção é interpretada como a representação dessa essência; em segundo lugar, o afeto de alegria ou de tristeza que nos advém com essa afecção, e que não indica senão a variação de nossa potência, é pensado como um signo de uma característica intrínseca do corpo que nos afeta, um signo a partir do qual julgamo-lo bom, se nos causa alegria, ou mau, se nos causa tristeza. Ora, todos os homens tendem a perseverar no seu ser, a conservar a sua existência, e têm consciência disso (Et., III, 9), porque percebem e afirmam o seu corpo como seu. Eles não têm da natureza das coisas um conhecimento prévio que os permita identificar quais entre elas favorecem sua potência singular; no entanto, por meio dos afetos de alegria e tristeza, têm um conhecimento espontâneo e imediato das coisas que lhes convêm ou não, e é à luz das paixões e da imaginação, ou seja, da imagem de tais coisas, que eles se orientam no seu esforço de autoconservação. Afirmar, como Spinoza, que eles têm consciência disso significa apenas dizer que esse esforço toma, na prática, uma direção específica, fá-los voltar-se a um ou outro objeto que, na sucessão das relações, dão conteúdo aos seus desejos, isto é, são representados, na imaginação, como coisas boas, como bens cuja posse causa alegria. Eles julgam boas as coisas porque as desejam, e não o contrário, e esse julgamento substitui neles conhecimento das causas. Com isso, seu modo de conduzir-se no mundo torna-se essencialmente finalista, na medida em que se resume a um empreendimento de apropriação de um objeto visto como um bem em si mesmo, e individualista, porque é governado por julgamentos parciais, por ideias que não põem em evidência as propriedades comuns das coisas, as relações, mas apenas os critérios de valor derivados das paixões que particularizam, na forma de uma consciência subjetiva, a percepção que os homens têm acerca de seu modo de operar no mundo.

É porque todos os homens buscam conservar sua existência singular e têm consciência disso, e, por outro lado, porque essa busca é, no mais das vezes, presidida pela imaginação e pelas paixões, que a composição de potências na produção coletiva das existências individuais, ou seja, a divisão social do trabalho, que define, para Spinoza, a cidade, acaba por ser dissimulada sob a aparência de um individualismo competitivo, que evoca a imagem hobbesiana da guerra de todos contra todos. A vida política transcorre no elemento da imaginação e das paixões, e por isso é lugar de conflito, ainda que seu fundamento - o fundamento da cidade - seja a potência coletiva dos homens que a compõem e que se constitui a partir das suas relações recíprocas. Esta é, a rigor, a razão de ser da política, mas as rivalidades nascidas entre homens por efeito do desacordo de suas paixões pode comprometer o funcionamento essencial da cidade: uma guerra civil interrompe os processos sociais de produção que geram a oferta dos bens de que os homens precisam para subsistir, e põe fim à segurança em nome da qual a vida política se organiza. Como, então, conferir estabilidade à convivência comum dos homens ante a instabilidade das paixões?

É impossível suprimir as paixões nos homens: eles são passionais em virtude da constituição de sua natureza. No primeiro capítulo do TP, Spinoza rejeitará a perspectiva moral da teoria política, que identifica nas paixões uma imperfeição da natureza dos homens, e adota, para remediar esse mal, um viés normativo, centrado no controle do corpo. Em lugar disso, ele afirmará que as paixões são modos de ser que pertencem à 
natureza dos homens e se explicam por causas determinadas. A história e a experiência demonstram que, em todas as épocas, os homens viveram em sociedade e sob a influência das paixões, e que essas duas dimensões só podem harmonizar-se se eles são capazes de estatuir um regime ou regra de vida comum que, em vez de confiar ao arbítrio de cada um, invariavelmente suscetível à força dos afetos, o dever de conduzir-se em paz nas suas relações com outros homens, ganhasse uma institucionalidade tal que os determinasse, contra ou a favor de sua vontade, a agir sempre em conformidade com o bem comum. A estrutura das relações comuns de produção, isto é, o campo da composição de potências singulares em uma potência coletiva, é, pois, complementada por uma superestrutura de instituições, que diz respeito às leis, aos costumes, aos aparelhos de poder, em suma, à forma de governo segundo a qual a potência coletiva dos cidadãos - a soberania - se distribui na dinâmica das relações que eles são determinados a estabelecer entre si.

No TP, Spinoza designa essas duas dimensões por dois conceitos distintos. A cidade (civitas) concerne ao nível das relações e é o próprio fundamento constituinte da vida política; sobre esta base, constituise o nível das instituições, o Estado (imperio). É nesse segundo nível que se coloca o problema das formas de governo como o problema da conciliação das paixões e dos desejos dos homens em um regime ou regra de vida comum que os torne tão livres quanto possível, ou seja, que favoreça o máximo possível seu direito natural, a potência singular pela qual afirmam a singularidade de sua essência. A afirmação da essência singular, que caracteriza essa liberdade, não se dá senão na política, e abrange os dois modos sob os quais essa essência se exprime: o corpo e, portanto, o acesso às coisas necessárias à conservação da existência, a autonomia de deslocamento, de associação etc. - e a mente - a liberdade de pensamento, de expressão etc.
Spinoza afirma que, se os homens se conduzissem antes pela razão que pelas paixões, se a natureza que faz deles seres passionais permitisselhes igualmente ter uma compreensão adequada de suas paixões, seriam dispensáveis os meios que, no Estado, os constrangem ou os persuadem a obedecer às leis. A figura mesma da autoridade seria prescindível. Os homens comporiam uns com os outros suas potências, engajando-se nas relações de produção que constituem a cidade, determinados pela noção comum de sua utilidade recíproca, sem se deixarem inimizar por efeito das paixões. Nesse caso, dispostos livremente a viver sob essa regra comum de vida, eles não precisariam submeter suas relações recíprocas ao mecanismo institucional e normativo de um Estado. Contudo, como observa Bove (2, p.12), a multidão é atravessada de conflitos e contradições, e a unidade de sua afirmação sempre está em questão. O projeto político do $\mathrm{TP}$, com efeito, não é pôr em discussão as formas de governo, elegendo a melhor entre elas, mas, antes, oferecer um conjunto de princípios práticos que permitam organizar, sob um regime monárquico, aristocrático ou democrático, uma sociedade de cidadãos livres. Com efeito, trata-se de constituir um regime comum de vida que permita aos homens exercer sua potência singular com máxima intensidade, o que significa promover entre eles o máximo possível de relações comuns, de modo a fazer-lhes presente a ideia de sua utilidade recíproca. Noutras palavras, um Estado onde os cidadãos são livres é aquele onde a distribuição da soberania favorece o mais possível a expressão dos direitos naturais individuais, e, nessa medida, expressa o mais possível o seu fundamento constituinte imanente: a potência coletiva da multidão.

É à luz dessa concepção que Spinoza considerará a democracia o mais natural dos regimes. O paradoxo da obra política de Spinoza consiste em que a democracia, forma de governo para a qual ele não indicará um receituário específico, é precisamente a única sobre a qual o 
TP verdadeiramente fala: seu objetivo aí não é outro senão dotar as formas monárquica e aristocrática de um conteúdo radicalmente democrático. A vida política é então pensada a partir de seu fundamento constituinte, isto é, a cidade, a dinâmica produtiva das relações que compõem o corpo político; e as formas de governo, conjunto das instituições que formam o Estado, são interpretadas, não como determinantes da vida política, mas, antes, como imagens dela.

Essa distinção permite trazer novamente à baila a comparação entre o homem-indivíduo e a sociedade-indivíduo. A cidade corresponderia, nos termos dessa analogia, ao corpo político, abrangendo o conjunto das relações comuns de produção em que se compõem umas com as outras as potências singulares dos cidadãos. A conhecida sentença de Marx, segundo a qual uma sociedade não é uma soma de indivíduos, sintetiza essa formulação: com efeito, a sociedade não se define pelos homens que fazem parte dela, mas pelas relações sob as quais essas partes, os homens, se mantêm unidas entre si. Essas relações estruturam a cidade como um corpo e exprimem a essência desse corpo político; isto significa que a conservação desse corpo político depende da reprodução de suas relações constitutivas. A dinâmica de produção dessas relações é, pois, uma dinâmica de reprodução das condições em que essas relações se dão, uma dinâmica de conservação de seu equilíbrio interno. Se, de acordo com Spinoza, uma coisa só pode ser verdadeiramente conhecida pela sua causa, então o que define uma sociedade-indivíduo, um corpo político, é seu modo de produção social, o modo através do qual essa sociedade conserva sua existência, reproduzindo a forma de suas relações características - as relações sociais -, ao mesmo tempo que, por meio delas, produz as coisas ou os bens de que têm necessidade para "regenerar continuamente"(E, II, post. 4), como o corpo humano, as suas partes constitutivas.

De outra parte, o Estado, entendido como o conjunto das instituições, pode ser assimilado à mente da cidade. Ele consubstancia o modo pelo qual a cidade - ou o conjunto de relações que a constitui - se percebe. O Estado é, por assim dizer, a consciência da cidade, uma ideia de sua imagem, sua representação inadequada, que, em lugar de exprimir a essência da cidade - a soberania da potência coletiva da multidão -, confunde-a com seus símbolos - como, por exemplo, a pessoa do soberano e sua autoridade, a letra da lei, a tradição etc. -, reconhecendo nestes, e nas formas de governo que com eles se identificam, o fundamento constituinte da vida política. A inversão operada por esse reconhecimento é similar à que a imaginação individual engendra com respeito à mente e ao corpo, supondo residir naquela, e não neste, a razão de ser dos estados da individualidade. O Estado é, como a mente, um modo de afirmar o corpo político como existente, e de afirmá-lo tal como ele é percebido. Os "órgãos” dessa percepção são as instituições sociais, os seus "aparelhos ideológicos", segundo a célebre conceituação de Althusser (1). Pode-se dizer, com esse mesmo autor, que as ideias produzidas por essas instituições são ideias materiais, isto é, são ideias que correspondem a uma prática material determinada e através das quais essa prática material é percebida e afirmada.

A relação entre a imagem ou representação da figura do Estado, afirmada no plano das instituições, e a imagem ou representação sob a qual os homens consideram a si mesmos, pode ser ilustrada pela demarcação que Althusser traça entre as noções de indivíduo e sujeito e pela forma através da qual este prevalece sobre aquele no processo político. Como os homens, indivíduos, são convertidos em sujeitos? Althusser propõe que essa passagem se realiza pela via da ideologia: a ideologia interpela os indivíduos como sujeitos. A ideologia é produzida e reproduzida por "aparelhos" do Estado, por instituições - a família, a escola, a igreja, a fábrica etc. - cuja função política é reafirmar um determinado modo de perceber as relações entre os homens, ou, antes, tornar reiteradamente 
presente uma determinada percepção que os homens têm de sua prática. Tais aparelhos não funcionam à maneira de máquinas de propaganda ou de manipulação: as ideias que se produzem a partir deles são, efetivamente, as ideias que correspondem à prática social, são representações que fazem sentido com a materialidade dessa prática. A ideologia, compreendida como conjunto de ideias ou representações sob as quais os homens percebem suas relações, nasce com essas mesmas relações, não como efeito delas, mas como o modo pelo qual os homens tomam consciência delas, isto é, as reconhecem e se reconhecem nelas. É esse reconhecimento que transforma os indivíduos, cujas relações constituem a cidade, em sujeitos de um Estado.

5.

Mas como essa transformação pode ser descrita a partir da teoria política spinozista?

A vida política, segundo Spinoza, é um processo de organização das relações entre os indivíduos, de composição de suas potências singulares ou direitos naturais em um processo de produção comum. Como visto, a tendência pela qual um homem é determinado a perseverar no ser, buscando o que convém à sua natureza ou essência singular, somente se pode efetivar na cidade, na vida política, através das relações que ele estabelece com outros indivíduos de natureza semelhante à sua e que, por isso, podem compor com ele uma potência coletiva mais eficaz na busca ou produção das coisas de que cada um, em particular, tem necessidade. A vida política é, pois, o lugar onde os homens podem entreter uns com os outros relações favoráveis às suas respectivas potências singulares e, portanto, ao seu esforço de autoconservação. Dessa perspectiva, a vida política apresenta-se, então, como um modo de organização dos "encontros" entre os indivíduos, dos encontros dos corpos e das mentes individuais, em oposição aos "choques" aleatórios e imprevisíveis com que, na solidão hipotética do estado de natureza, um homem se defrontaria a todo instante. Na cidade, as relações dos homens se subordinam a um regime de regularidade: a sua produção é também reprodução das condições sob as quais produzem, e sua dinâmica interna de autoconservação é, ao mesmo tempo, um elemento constitutivo e dependente da dinâmica social de conservação do corpo político. Assim, uma vez que sua existência individual envolve, como sua causa, a existência da cidade, a tendência que determina os homens a produzir sua existência também os determina a reiterar as relações por meio das quais se engajam nessa produção - as próprias relações sociais.

Essas relações realizam-se, pois, sob a determinação da "essência" do corpo político que constituem, isto é, a forma característica das relações sociais em uma cidade exprime seu modo de ser, seu modo de produção. Isto significa que, na vida política, as relações comuns que os homens são determinados a estabelecer revestem determinada forma de acordo com o modo pelo qual essa sociedade existe e se reproduz, conservando essas mesmas relações constitutivas. Por isso, os homens, na vida política, pensam e operam dentro da lógica de conservação do corpo político: eles estão submetidos a certos tipos, e não outros, de afecções, e estas são percebidas por certos tipos, e não outros, de ideias de afecções na imaginação. Em virtude da contínua reiteração das relações através das quais o indivíduo pensa e opera, e das condições sob as quais essas relações se dão, o regime de reprodução social em que ele está inserido como "parte" tende a fazê-lo imaginar sua prática como uma sucessão estável. Os objetos - as afeç̧ões - apresentam-se-lhe constantemente sob as mesmas relações e seguem freqüentemente uma mesma ordem, de tal sorte que, por mais complexa que seja a dinâmica social, um indivíduo é capaz de reconhecer as coisas que o afetam e os efeitos que pode esperar delas. Essa previsibilidade permite- 
lhe supor que as coisas atendem a fins próprios, e, assim, ele pode colocarse, em relação a elas, como sujeito, confundindo as afecções, derivadas de causas externas que determinam sua percepção dos outros corpos e do seu próprio corpo, com “objetos” acerca dos quais ele é capaz de formar uma percepção autodeterminada.

A percepção espontânea que os homens fazem acerca das coisas, cujas imagens lhes são recorrentemente presentes em virtude da regularidade das afecções, produz neles uma ideia reflexiva, isto é, uma ideia que tem por objeto a ideia de uma afecção, a ideia de uma imagem: assim, um corpo exterior modifica o corpo de um homem por meio de uma afecção, de uma imagem material; tal homem percebe a existência desse corpo exterior por uma ideia de sua imagem ou afecção, e, em um nível reflexivo, percebe como seu o corpo afetado e como sua a mente que forma dessa afecção uma ideia. A mente é uma ideia do corpo, uma ideia do conjunto de afecções que modificam o corpo em dada atualidade. Ela afirma, pela percepção dessas afecções, a existência do corpo, mas, no nível reflexivo, converte-se ela mesma em objeto de outra ideia, pela qual se percebe a si própria. A mente tem, pois, uma ideia de si mesma, uma consciência; na medida em que a mente é uma ideia do corpo e este é percebido por suas afecções, a mente existe como um conjunto de ideias de afecções que corresponde ao conjunto das partes afetadas do corpo. Como as ideias de afecções envolvem, sempre, uma imagem do corpo afetante e uma imagem do corpo afetado, o substrato comum a todas as ideias de afecções é a imagem desse corpo, e por isso a mente percebe-o como seu. O que reduz a variedade das ideias de afecções à unidade da consciência é a ideia que a mente é determinada a formar de si mesma, a capacidade da mente de vincular as representações das coisas percebidas a uma representação de si mesma, na medida em que as percebe. Essa percepção espontânea toma nela a forma de uma consciência subjetiva.
Aimaginação, segundo Spinoza, é, em todos os homens, a percepção comum e espontânea das modificações produzidas por causas externas sobre seu modo de vida. Se, no estado de natureza, um homem viveria ao acaso de encontros, que fariam variar indefinidamente suas representações imaginárias de mundo, ele é, na vida política, submetido a um tal regime de previsibilidade que sua imaginação é determinada a revestir a forma de uma composição estável de representações, de idéias de afecções constantemente concertadas nas mesmas associações, cujos conteúdos informam sua visão de mundo. Desse modo, a imaginação individual tende a estabilizar-se na forma determinada de uma consciência subjetiva. As idéias de imaginação - idéias dos efeitos ou das imagens materiais das coisas que nos afetam são o elemento constitutivo da consciência, e é precisamente neste teatro de formas que são plasmados, com aparência de criações espontâneas do espírito, os juízos e opiniões, os valores e, por conseguinte, as disposições de obediência e de reconhecimento de autoridade.

A consciência é a imaginação socialmente estruturada, modificada pela interpelação ideológica. O repertório estável das representações dos homens corresponde ao regime regular de suas práticas sociais, exprime a percepção dominante ou universal que eles têm acerca de tais práticas, e estas exprimem a forma dominante ou universal das relações sociais que eles estabelecem uns com os outros, cuja reprodução é efeito e condição da dinâmica de conservação do corpo político. Noutros termos, a consciência é a imaginação estruturada segundo a ideologia dominante (ou universal) correspondente à forma dominante (ou universal) das relações sociais que caracterizam o corpo político, que definem sua dinâmica imanente de conservação ou seu modo de produção.

A diferença entre "imaginação" e "consciência", no plano individual, é análoga à diferença entre "multidão" e "povo", no plano político, e remete à distinção conceitual, cunhada por Althusser (1), entre 
"indivíduo" e "sujeito". A noção de "povo" designa sempre um sujeito político, que se define em relação a um Estado, tanto no sentido de "sujeição" - sujeito ao direito, isto é, à lei, à autoridade do Estado - quanto no sentido de "autonomia" - sujeito de direito, ou seja, sujeito coletivo cuja vontade faz o direito e legitima a autoridade do Estado. A multidão, conforme foi visto, é anterior, por definição, ao povo, assim como a cidade é anterior ao Estado. Ela não constitui um sujeito, segundo a acepção dada há pouco: ela é um indivíduo, definido por suas relações de produção, de composição de potências, e consiste, como potência coletiva assim constituída, no corpo político, no corpo da cidade. O Estado é, por assim dizer, uma superestrutura mental em relação a essa estrutura corporal: o conjunto de suas instituições diz respeito ao modo pelo qual as relações constitutivas desse corpo são percebidas, e abrange, na sua unidade, uma visão de mundo determinada pelos efeitos dessa percepção. É no nível do Estado - na esfera das instituições - que a multidão, indivíduo composto de indivíduos, se concebe como povo, sujeito composto de sujeitos; e é nesse mesmo nível que as imaginações individuais - e os juízos particulares acerca do bom e do útil - convergem em uma mesma forma de consciência subjetiva -, em um conjunto de valores morais universais.

Amultidão, pois, é sempre sujeito no Estado? Sim, se considerarmos que ela se representa como povo, na medida em que sua potência coletiva - a soberania - é, no Estado, no âmbito de uma forma de governo definida, exercida como poder por uma autoridade. A multidão, está visto, engloba dominantes e dominados: todos são partes do corpo político. A separação ocorre no nível do Estado, isto é, no nível das instituições, segundo o lugar ou a função que cada cidadão desempenha nelas, e às quais corresponde um grau determinado de poder, uma parcela da potência da multidão. Spinoza não se ocupa de distinguir os variados mecanismos de legitimação dessa autoridade: quer tenha ela obtido anuência dos demais cidadãos para ocupar essa posição, quer a ocupe em virtude de um direito hereditário, divino ou de guerra, o fato é que, dada a maneira pela qual a potência da multidão se distribui, como graus de poder, entre os cidadãos, aqueles que se apropriam de uma parcela maior dessa potência são aqueles que governam o Estado. $\mathrm{O}$ fundamento do poder político no Estado é a potência da multidão, e a legitimação desse poder reflete apenas o modo através do qual essa potência se distribui entre os cidadãos.

Esta distribuição de poder não resulta de um contrato social. Ela é, por assim dizer, conjuntural, uma vez que exprime a institucionalidade atual dada às relações que os cidadãos estabelecem entre si. Se, por um lado, a cidade, o corpo político, é o fundamento constituinte que atravessa todas as formas de organização da existência dos homens - porque os homens, conforme a história o demonstra, sempre viveram em sociedade, e, conforme sua natureza determina, não podem efetivar seu direito natural senão nas relações comuns com outros homens -, por outro lado a forma de governo sob a qual tais relações se institucionalizam não é perene, e a sua estabilidade no tempo depende da conservação da estrutura de relações a partir da qual ela se erigiu. Noutras palavras, para que uma forma de Estado siga existindo, é preciso que os homens que dele participam, ao mesmo tempo que se empenham na produção de efeitos bons ou úteis à conservação de suas existências singulares, sejam determinados a produzir efeitos bons ou úteis à conservação do Estado. No entanto, quando essa correspondência deixa de existir, isto é, quando os homens deixam de perceber, em uma dada forma de Estado, um elemento útil ou bom à conservação de suas existências singulares, eles podem buscar outras formas de estabelecer relações, de conjugar suas potências, dando ao corpo político uma outra composição. Nesse caso, pode-se dizer que a multidão se reapropria de sua potência coletiva, da soberania, e, a partir disso, refunda o Estado. Ela deixa de operar como sujeito, e passa a atuar como 
indivíduo. É essa inflexão que caracteriza o processo revolucionário, tal como Spinoza sugere no TP (III, 9).

Da mesma forma que o corpo humano, sob ação de afecções, pode ser "sujeito de contrários", a unidade da multidão não exclui o conflito do corpo político. Em um, como em outro, a conservação da existência não diz respeito à ausência de modificações, à imobilidade - o equilíbrio dinâmico dos corpos depende da regeneração de suas partes constitutivas, assim como a estabilidade dos Estados pode requerer a realização de reformas em suas instituições -, mas concerne, antes, à preservação da estrutura característica das relações em que suas partes constitutivas se compõem. No corpo político, essas relações são as relações sociais de produção, e é da reprodução da estrutura característica das relações sociais que depende a conservação do Estado, entendido como forma de governo ou regime de distribuição, entre os cidadãos, da potência coletiva da multidão.

Dentro do Estado, a parcela de poder - político, econômico, simbólico - de cada cidadão é determinada por sua posição nessa distribuição, e não por sua potência singular isoladamente considerada. Por outro lado, uma vez que os homens tendem, por natureza, a buscar modos de composição de relações melhores e mais úteis à sua conservação, o Estado, ao dar institucionalidade às relações, estabiliza-as e as faz convergir para a reprodução da estrutura de relações que caracteriza a sua forma. Como os homens empreendem essa busca, guiados pelas paixões e pela imaginação, a conservação do Estado como conjunto de instituições passa pelos mesmos mecanismos imaginativos e passionais pelos quais os homens operam. Por isso, as instituições, que definem o espaço da prática social ao delinear o circuito através do qual se dão as relações, funcionam como grandes "corpos" dentro do corpo político, "corpos" que determinam por assim dizer o tipo de afecções a que os homens desse corpo político são sujeitos. São as ideias dessas "afecções políticas", isto é, a percepção espontânea de sua prática social, que informam o conteúdo da imaginação e das paixões dos homens. Por essa razão, se assegurar a estabilidade do Estado implica conter a multidão dentro de certos limites - afetivos, imaginativos -, as instituições que caracterizam essa forma de Estado tendem a incitar as paixões ou fazer circular as imagens que concorrem para a manutenção de sua estrutura de poder por meio da qual a potência da multidão se distribui entre os cidadãos.

Seria controverso sustentar que Spinoza defende, no TP, a saída revolucionária, visto que, em variadas passagens, ele define, como razão de ser do Estado, a garantia da paz e da segurança. Por outro lado, as diretrizes práticas de organização que Spinoza recomenda, no TP, aos Estados monárquico e aristocrático - a divisão de poderes, a criação de assembleias e conselhos de composição multitudinária e rotativa, a propriedade comum do solo etc. - não têm outro fim que, preservando os símbolos e aparências de cada uma, dotar essas formas de governo de uma institucionalidade democrática. A democracia, como Spinoza a concebe, é o mais natural dos regimes porque favorece em maior grau a realização do direito natural dos homens, na medida em que produz uma estrutura mais dinâmica e equânime de distribuição da potência coletiva da multidão. Permitindo aos cidadãos tomar parte nas deliberações políticas e assegurando-lhes a liberdade de pensamento e o acesso aos bens necessários à vida, ela favorece a busca de cada um deles por estratégias de composição de relações melhores e mais úteis. Embora, por essas mesmas razões, o regime democrático pareça mais suscetível à instabilidade, a liberdade de constituir relações, de conjugar suas potências em uma prática comum tende a tornar mais presente aos homens a ideia de sua utilidade recíproca. Se o corpo humano é tanto mais potente quanto maior sua capacidade de ser afetado e assimilar modificações (E, IV, 38), e se a mente se torna, por isso, tanto mais apta a perceber um grande número 
de coisas e formar uma ideia mais perfeita de seu estado, pode-se dizer que a potência coletiva do corpo político é tanto maior quanto mais as suas relações constitutivas favorecerem a afirmação dos direitos naturais individuais. Assim também, o Estado será tanto mais conforme à natureza dos homens (e por isso mais estável) na medida em que suas instituições favorecerem as paixões ou afetos que disponham os homens a perceber como coisa boa ou útil as suas próprias relações comuns.

\section{IMAGES AND ANALOGIES OF THE BODY AND THE MIND IN SPINOZA'S POLITICS}

Abstract: This article proposes to study some interpretative possibilities raised by analogy of the image of the human body and the structure of the political body. Beginning by discussing the dynamics of production of bodies in nature, the text provides an analysis of the contradiction between two thesis presented in the work of Spinoza - one in his ontology, and another in politics -, which are formulated in terms of the analogy of human body with the political body. Then this analogy spreads in a comparison between the human mind and what might be called a "mind" of the political body, by discussing the two levels of politics - the city (civitas) and the State (imperio). Finally it is proposed an interpretation of the production process of ideas in political life in the light of Althusserian theory of ideology.

Keywords: Spinoza, politics, body, imagination, ideology.

\section{REFERÊNCIAS BIBLIOGRÁFICAS:}

1. ALTHUSSER, Louis. Idéologie et appareils idéologiques d'État (Notes pour une recherche).Positions. Paris: Les Éditions Sociales, 1976.

2. BOVE, Laurent. Introduction. In: SPINOZA, B. Traité Politique. Paris: LGF, 2002.

3. MATHERON, Alexandre. Individu et communauté chez Spinoza. Paris: Minuit, 1988

4. NEGRI, Antonio. A anomalia selvagem. São Paulo: Ed. 34, 1993.
5.. SPINOZA, Baruch. Ética. Tradução de Tomaz Tadeu. Belo Horizonte: Autêntica, 2008.

6.. SPINOZA, Baruch. Tratado da reforma da inteligência. São Paulo: Martins Fontes, 2004.

7.. SPINOZA, Baruch. Tratado teológico-político. Tradução e prefácio de Diogo Pires Aurélio. São Paulo: Martins Fontes, 2003.

8.. SPINOZA, Baruch. Tratado político. Lisboa: Editorial Estampa. 1977. 